\title{
Contribution Among Contract Breakers: A Case Comment on isfeld V. Petersen Pontiac Buick GMC (Alta.) Inc.
}

\author{
RANJAN AGARWAL ${ }^{*}$ AND GANNON BEAULNE**
}

\section{INTRODUCTION}

Courts have struggled with the "somewhat vexed" subject of contribution since its inception. ${ }^{1}$ The mechanism of contribution seems well-suited to mitigate the harshness attending cases in which two or more people might be responsible for a single loss or damage but the plaintiff has elected not to sue one or more of these people. This mechanism, however, has been historically unavailable to defendants in many circumstances, and courts have enjoyed little success in dealing with this perceived injustice.

In tort law, this problem was remedied by the introduction of contributory negligence and tortfeasor legislation across Canada, creating a statutory right of contribution and indemnity. However, the boundaries of this right were uncertain. In the 1960s and 1970s, a flurry of judgments, working papers, and academic commentaries considered the extent to which these statutes could apply among those who breached independent contracts with the plaintiff but caused or contributed to the same loss or damage.

When the dust settled, the courts in many provinces, including Ontario and Alberta, had largely accepted that the statutory right of contribution only applies among tortfeasors. The controversy surrounding the availability of contribution thus receded into the background, and defendants in non-tort cases were left without recourse. Now this controversy has been reignited by the Alberta Court of Appeal in its recent decision in Isfeld v. Petersen Pontiac Buick GMC (Alta.) Inc. ${ }^{2}$ If followed in other provinces, Petersen Pontiac will signal new life — and a new legal basis — for contribution and indemnity claims.

This comment argues that Petersen Pontiac contains an important equivocation about the legal basis for bringing a third-party claim for contribution in non-tort cases. This equivocation will introduce confusion into the foundation of the contribution mechanism, rendering principled decision-making impossible in hard cases. This comment concludes, however, that recognizing a right of contribution that extends consistently throughout the civil law is desirable and, ultimately, is defensible under restitutionary principles. So, if the necessary adjustments are made, Petersen Pontiac offers Canadian courts an enticing opportunity to effect positive change in a confounded area of law and to close the door on a decades-old controversy.

BA (Hons) (Alberta), MA (Carleton), LLB (Ottawa), LLM (Osgoode Hall). Ranjan Agarwal is a partner in the litigation department at Bennett Jones LLP in Toronto. He was called to the Bar of Ontario in 2004.

BA (Hons) (Queen's), JD (Queen's). Gannon Beaulne is an associate in the litigation department at Bennett Jones LLP in Toronto. He was called to the Bar of Ontario in 2013.

For this “somewhat vexed" language, see Henuset Bros Ltd v Pan Canadian Petroleum Ltd (1977), 82 DLR (3d) 345 at 360 (Alta SC) [Henuset Bros].

2013 ABCA 251, 364 DLR (4th) 724 [Petersen Pontiac], rev'g Isfeld v Petersen Pontiac Buick GMC (Alta) Inc, 2012 ABQB 444, 2012 ABQB 444 (CanLII) (written reasons for judgment dated 6 July 2012, supplementing oral reasons for judgment dated 17 May 2012). 


\section{BACKGROUND}

Lawrence Isfeld and his numbered company (Isfeld) and Petersen Pontiac Buick GMC (Alta.) Ltd. (Petersen Pontiac) owned adjoining lots. ${ }^{3}$ Petersen Pontiac's lot had an access easement over Isfeld's lot which was registered against both titles. Isfeld had a right of first refusal to buy Petersen Pontiac's lot, which was protected by a caveat on title.

For years, Petersen Pontiac leased Isfeld's lot. When the original lease was set to expire, the parties entered into a Lease Renewal Agreement (the Agreement). Under the Agreement, Isfeld agreed to give up his right of first refusal, and Petersen Pontiac agreed to narrow the width of its easement and discharge it entirely if it sold its lot to a purchaser who could get direct access from the front of the property. After executing the Agreement, the parties returned it to Isfeld's lawyer, John Campbell (Campbell).

Before he received the executed Agreement, Campbell prepared a discharge of Isfeld's right of first refusal protected by the caveat against Petersen Pontiac's lot. Campbell registered this discharge two weeks later even though the right of first refusal had expired by the Agreement's terms the month before. Campbell informed Petersen Pontiac's lawyer that he would try to register the Agreement nonetheless but that a supplemental easement amending agreement might be required. As predicted, the Land Titles Office refused to accept the Agreement as amending the easement.

Campbell prepared the supplemental agreement and forwarded it to Petersen Pontiac's lawyer. This supplemental agreement, however, omitted the condition that Petersen Pontiac would discharge the easement if it sold its lot to a purchaser who could get direct access to the property. Although they had noticed this omission, Petersen Pontiac and its solicitor did not bring it to Campbell's attention. Instead, Petersen Pontiac signed the supplemental agreement and returned it to Campbell.

Meanwhile, Petersen Pontiac had agreed to sell its lot without disclosing its contractual obligations concerning the easement amendment. Petersen Pontiac retained a different lawyer for the purposes of this sale and did not fully disclose its contractual obligations. The purchaser filed a caveat against its lot. By this time, Campbell had already discharged Isfeld's right of first refusal, but Isfeld had not yet signed the supplemental agreement. The purchaser's successors ultimately gained direct access, but the lot remained subject to the original easement. The new owners obtained a permanent injunction preventing their access from being blocked.

Isfeld sued both Petersen Pontiac and Campbell. Campbell issued third-party notices against Isfeld claiming contributory negligence and against Petersen Pontiac claiming contribution and indemnity as a result of Petersen Pontiac's failure to notify him or Isfeld about the sale of Petersen Pontiac's lot. In an agreed statement of facts, Campbell acknowledged that he had breached his retainer agreement and acted negligently by discharging the caveat without informed consent and contemporaneous registration of the supplemental agreement. 


\section{The TRIAL DeCiSION}

After a trial of the issues, Justice Jerke of the Alberta Court of Queen's Bench gave his oral reasons for judgment on 17 May 2012. First, he found Petersen Pontiac liable for breach of contract on the ground that it "cannot ... now fulfill its contractual obligations because the purchaser ... did not agree to accept, and cannot be made to accept, responsibility for Petersen Pontiac's obligations."4 He did not find Petersen Pontiac liable for negligence. Second, he found Campbell liable on five grounds:

- $[\mathrm{H}] \mathrm{e}$ should not have discharged the right of first refusal until the Easement Amendments had been registered; ...

- $[\mathrm{He}]$ could have protected the plaintiffs by placing a caveat on Lot $4 \mathrm{~A}$ claiming an interest pursuant to the Easement Amendments [and failed to do so];

- $[\mathrm{He}]$ failed to ascertain the nature of the document required by the Land Title Office to change the easement;

- $[\mathrm{He}]$ did not include a term dictating the conditions for discharge of the easement when he prepared the Easement Amending Agreement; and

- $[\mathrm{He}]$ failed to register the Easement Amending Agreement. ${ }^{5}$

Thus, Campbell had both acted negligently and breached his retainer agreement. Justice Jerke rejected Campbell's allegation of contributory negligence because Isfeld had been entitled to "expect that ... any actions required to protect [his] interests were complete." ${ }^{\circ} \mathrm{He}$ concluded that Isfeld had suffered damages in the amount of $\$ 208,333$. $^{7} \mathrm{He}$ continued, however, that Petersen Pontiac's and Campbell's liabilities were separate and distinct, notwithstanding the fact that each wrongdoing had generated the same result, namely, that the easement amendment was ineffective against the purchaser. ${ }^{8}$ Moreover, he found that Campbell's liability was "secondary." Therefore, Campbell could collect the full amount of damages from Petersen Pontiac through an assignment of the judgment once he had paid Isfeld.

\section{The Court of Appeal's Reasons}

Petersen Pontiac appealed from Justice Jerke's finding of secondary liability. Writing for the Alberta Court of Appeal, Justice Hunt allowed the appeal. She found that the concept of secondary liability does not apply to contract or mixed-contract-and-tort cases. ${ }^{10}$ The Court therefore invited counsel to provide authority on how to apportion liability where separate 
contract breakers had caused or contributed to the same loss or damage. Counsel agreed that no such authority existed.

Absent any direct authority, Justice Hunt identified two potential bases for apportioning liability: ${ }^{11}$

1. The statutory right of contribution under the Contributory Negligence Act ${ }^{12}$ and the Tort-feasors Act; ${ }^{13}$ and

2. The basic principles of contract law.

Justice Hunt rejected the first potential base. She affirmed the traditional view that these statutes only apply among tortfeasors, ${ }^{14}$ echoing a comment by Justice La Forest in Caisse populaire d'Inkerman Ltée v. Doiron that a liberal interpretation of the term "fault" would "be stretching a point and ignoring the antecedents of the Act.". 15

Turning to the second potential base, Justice Hunt repeated an oft-quoted observation by Stephen Waddams that it is "anomalous that a defendant's right to claim contribution should vary according to the form of action chosen by the plaintiff." 16 She also noted Ernest Weinrib's view that, since it is unfair for defendants to bear more than their shares of the liability, "there is no reason why contribution between contract breakers should not be available on a restitutionary basis." 17

Having satisfied herself that the relevant academic commentaries supported recognizing a right of contribution among independent contract breakers, Justice Hunt considered the wider jurisprudence on the related notions of contribution and apportionment. She identified three particularly helpful judicial comments. First, in his dissenting opinion in Smith $v$. McInnis, Justice Pigeon stated that, although the doctrine of contributory negligence does not apply in contract cases, "the principle of causality must be applied and, therefore, there has to be an apportionment in the rare case of separate breaches of contract having contributed to a single loss." ${ }^{\prime 18}$ Second, in Giffels Associates Limited v. Eastern Construction Company Limited, Chief Justice Laskin stated:

I am prepared to assume, for the purposes of this case, that where there are two contractors, each of which has a separate contract with a plaintiff who suffers the same damage from concurrent breaches of those

Petersen Pontiac, supra note 2 at paras 37-38.

RSA 2000, c C-27.

RSA 2000, c T-5.

Ibid at para 42. For further discussion and general references on this matter, see infra note 28.

(1985), 61 NBR (2d) 123 at para 51 (CA) [Doiron].

SM Waddams, The Law of Contracts, 6th ed (Toronto: Canada Law Book, 2010) at 576. Justice Hunt also relied on a United Kingdom statute permitting contribution among independent contract breakers. The Civil Liability (Contribution) Act 1978(UK), c 47, s 1(1), provides that "any person liable in respect of any damage suffered by another person may recover contribution from any other person liable in respect of the same damage (whether jointly with him or otherwise)."

17 Petersen Pontiac, supra note 2 at para 44, citing Waddams, ibid at 576. See also Ernest J Weinrib, "Contribution in a Contractual Setting" (1976) 54:2 Can Bar Rev 338 at 348-49.

[1978] 2 SCR 1357 at 1381. 
contracts, it would be inequitable that one of the contractors bear the entire brunt of the plaintiff's loss, even where the plaintiff chooses to sue only that one and not both as in this case. ${ }^{19}$

Third, Justice La Forest commented in Doiron that "the doctrine of apportionment of loss where contributory negligence arises in contract cases is here to stay," 20 and he continued that "there never developed in contract law the rigid rules against apportionment of loss that prevailed in tort law and, in fact, loss was apportioned in the rare cases where separate breaches of contract contributed to a single loss." 21

After reviewing these cases and commentaries, Justice Hunt quickly dismissed the objection that causation and remoteness are obstacles to apportioning liability among independent contract breakers. ${ }^{22}$ She concluded:

I see no impediment in contract law to dividing liability between two parties who have breached two different contracts, causing the same damages to a plaintiff. It is appropriate to apportion liability between Campbell and Petersen Pontiac, since the liability of each flowed from a breach of contract (and, in Campbell's case, from negligence as well). ${ }^{23}$

Since Justice Jerke had found that both parties contributed to Isfeld's damages and did not find that one party was more responsible than the other, Justice Hunt ordered an equal apportionment of liability between Petersen Pontiac and Campbell. ${ }^{24}$ In a single paragraph at the end of her judgment, she added that, in her view, the same result could be achieved on the basis of equitable principles. ${ }^{25}$

\section{Analyzing the Court's Decision}

All nine common law provinces and the territories of Canada have enacted legislation repealing the common law bar on contribution among tortfeasors. Under Ontario's Negligence Act, the statutory right of contribution extends to all persons who caused or contributed to the same loss or damage by their "fault or neglect." ${ }^{26}$ Other provincial statutes contain similar language. Much judicial ink has been spilled over the scope of the term "fault," and some courts have found that it is broad enough to subsume cases sounding in contract. ${ }^{27}$ Ontario and Alberta courts, however, have traditionally confined the application of this statutory right to tortfeasors. ${ }^{28}$

[1978] 2 SCR 1346 at 1355 [Giffels].

Doiron, supra note 15 at para 46.

Ibid at para 55.

Petersen Pontiac, supra note 2 at para 50.

Ibid at para 52 .

Ibid at para 53.

Ibid at para 54

RSO 1990, c N.1, s 1.

See e.g. ACA Cooperative Association Ltd v Associated Freezers of Canada Inc et al (No 3) (1992), 113

NSR (2d) 1 at paras 110-23 (CA); Groves-Raffin Construction Ltd v Bank of Nova Scotia, (1974), 51

DLR (3d) 380 at 414-15 (BCSC), rev'd on other grounds (1975), 64 DLR (3d) 78 (BCCA).

28 See e.g. Allcock, Laight \& Westwood Ltd v Patten (1966), [1967] 1 OR 18 (CA) [Allcock]; Giffels, supra note 19; Henuset Bros, supra note 1 at 362. For example, in Indal Metals $v$ Jordan Construction Management Inc (1994), 29 CPC (3d) 361 (Ont Ct J (Gen Div)), Justice Borins found that a defendant in a contract action could not avail itself of the right to contribution and indemnity set out in the Negligence Act, supra note 26, s 1, since it was not a tortfeasor. 
Petersen Pontiac does not challenge this traditional interpretation. To the contrary, Justice Hunt was not persuaded that the term "fault" is broad enough to cover contract breakers. ${ }^{29}$ Instead of artificially broadening the statutory right, she proposed a novel alternative basis for permitting contribution among contract breakers: the basic principles of contract law. Unfortunately, problems with this approach are immediately apparent when considering the procedural path defendants would have to follow to assert this new right of contribution where, for example, two independent contract breakers may have caused or contributed to the same loss or damage but only one has been sued.

The analysis portion of this case comment proceeds in three parts. First, it draws a distinction between apportioning liability and bringing a third-party contribution claim, emphasizing that each mechanism entails different procedural considerations. Second, it maintains that Petersen Pontiac, although masquerading as an apportionment case, purports to create a right of contribution which in many cases would require a defendant to bring a third-party claim and, thus, show a legal basis for commencing an action against the third party - an impossible task under the basic principles of contract law. Third, it investigates whether restitutionary principles offer a valid basis for bringing third-party claims. Finding that they do, it concludes that, although Petersen Pontiac cannot be accepted wholesale, it offers a valuable opportunity to recognize a wider right of contribution.

\section{A. Untangling the Procedural Knot}

Petersen Pontiac conflates two related but distinct mechanisms: the apportionment of liability and the commencement of a third-party claim for contribution and indemnity against a person who has not been sued. ${ }^{30}$ This latter mechanism involves an additional procedural step.

Petersen Pontiac is technically an apportionment case. Isfeld sued Petersen Pontiac and Campbell. In turn, Campbell claimed contributory negligence against Isfeld — which Justice Jerke rejected — and issued a third-party notice claiming contribution against his codefendant, Petersen Pontiac. Although this information is not contained in either written judgment, we can speculate with some confidence that Campbell brought his third-party notice under Rule 3.43 of the Alberta Rules of Court. Subrule (1) of this rule reads:

If a defendant claims a contribution or indemnity, or both, against a co-defendant under the Tort-feasors Act or the Contributory Negligence Act,

(a) the defendant may file and serve on a co-defendant a notice in Form 15 claiming a remedy under either or both of those Acts,

Petersen Pontiac, supra note 2 at para 51.

Traditionally, courts assigned degrees of fault only among parties to the action. See e.g. Martin $v$ Listowel Memorial Hospital (2000), 51 OR (3d) 384 at paras 30-48 (CA). Under the Negligence Act, supra note 26 , it now appears that courts can apportion fault to a non-party. See Taylor $v$ Canada (Minister of Health), 2009 ONCA 487, 95 OR (3d) 561 at paras 23-29 [Taylor]. It is unclear whether this line of authority extends beyond the statutory right of contribution, since the Court of Appeal in Taylor at para 27 relied in part on the use of the word "person" rather than "party" in section 1 of the Negligence Act (ibid). 
(b) neither the defendant nor the co-defendant need file a pleading in respect of a claim or defence under those Acts unless the Court otherwise orders, and

(c) a third party claim need not be filed and served on the co-defendant. ${ }^{31}$

At trial, Petersen Pontiac was found liable for breach of contract, and Campbell was found liable for both breach of contract and negligence. On appeal, Justice Hunt considered whether she could apportion fault between two parties to the action, Petersen Pontiac and Campbell. She decided that, although the statutory right of contribution was unavailable, the basic principles of contract law could support a right of contribution and, thus, permit the apportionment of liability. ${ }^{32}$

This result is confusing. By its express terms, Rule 3.43 only permits contribution claims brought under the Tort-feasors Act or the Contributory Negligence Act. ${ }^{33}$ But Justice Hunt accepted that the statutory right of contribution does not extend to independent contract breakers. Thus, Campbell and any other defendant asserting a contract-law-based right of contribution should not be entitled to issue a third-party notice under Rule 3.43 of the Alberta Rules. Nor should they be entitled to proceed under section 6 of the Contributory Negligence Act. $^{34}$

To assert a contract law-based right of contribution, defendants will be confined to the general procedure for bringing third-party claims. In Alberta, this procedure is set out in Rule 3.44 of the Alberta Rules. ${ }^{35}$ This rule provides:

3.44 A defendant or third party defendant may file a third party claim against another person who

(a) is or might be liable to the party filing the third party claim for all or part of the claim against that party,

(b) is or might be liable to the party filing the third party claim for an independent claim arising out of

(i) a transaction or occurrence or series of transactions or occurrences involved in the action between the plaintiff and the defendant, or

(ii) a related transaction or occurrence or series of related transactions or occurrences, or

Alta Reg 124/2010, r 3.43(1) [Alberta Rules]. See also Rules of Civil Procedure, RRO 1990, Reg 194, r 28.01 [Ontario Rules]. Subrule 2 of this rule provides that a defendant who claims contribution from a co-defendant shall do so by way of cross-claim.

Justice Hunt does not appear to limit her decision to the apportionment of liability but, rather, expressly purports to recognize a substantive right of contribution (Petersen Pontiac, supra note 2 at para 44). This problem would apply equally in Ontario. See Ontario Rules, supra note 31, r 28.01.

See also Negligence Act, supra note 26, s 5. The Ontario Court of Appeal interpreted section 5 of the Negligence Act in HSBC Securities (Canada) Inc v Davies, Ward \& Beck (2005), 74 OR (3d) 295 at paras 50-88. It found that section 5 creates a procedural avenue for asserting the substantive right of contribution found in section 1 . Thus, if the statutory right of contribution does not apply, parties cannot avail themselves of the Negligence Act's procedural mechanism for asserting that right. Supra note 31. See also Ontario Rules, supra note 31, r 29.01. 
(c) should be bound by a decision about an issue between the plaintiff and the defendant.

Although Justice Hunt appears to resolve the appeal by apportioning fault between Petersen Pontiac and Campbell, the right of contribution that she purports to recognize will require defendants to bring regular third-party claims.

\section{B. The Legal BASIS FOR Claiming CONTRIBUtion}

In both Alberta and Ontario, defendants can commence third-party claims against nonparties in three circumstances:

1. The third party is or may be liable to the defendant for all or part of the plaintiff's claim;

2. The third party is or may be liable to the defendant for an independent claim arising out of the same or a related transaction, occurrence or series of transactions or occurrences involved in the main action; or

3. The third party should be bound by the determination of an issue arising between the plaintiff and the defendant. ${ }^{36}$

To maintain a third-party claim, a defendant must show a legal relationship with the proposed third party on which it can ground a cause of action. The quintessential articulation of this principle was furnished by Justice Laskin (as he then was) writing for the Ontario Court of Appeal in Allan v. Bushnell T.V. Co. Ltd. $^{37}$ He stated:

\footnotetext{
What, in my view, is central to resort to third party proceedings is that the facts upon which the plaintiff relies against the defendant should issue out of the relations between the defendant and the third party ... and, such claim [that of the defendant for redress against the third party] would ordinarily arise out of relations between the defendant and the third party anterior to those between the plaintiff and the defendant which precipitated the main action. ${ }^{38}$
}

In other words, there must be a connection of fact or subject matter between the cause of action on which the plaintiff sued and the defendant's claim against the third party ${ }^{39}$ Courts will therefore scrutinize the relationship between a defendant and a third party to find a locus for a right of contribution - for example, an express or implied contract, a statutory right or some other legal or equitable right. ${ }^{40}$ Absent a legal basis, the third party is entitled to

Alberta Rules, supra note 31, r 3.44; Ontario Rules, supra note 30, r 29.01.

[1968] 1 OR 720 (CA) [Allan].

Ibid at 723 .

Ibid. Despite subsequent changes to the Ontario Rules, this case is still cited as good law: see e.g. Woodcliffe Corp et al $v$ Rotenberg et al, 201 OAC 201 at para 11 (CA), leave to appeal to SCC refused 31142 (16 February 2006). It has also been regularly applied in Alberta and other Canadian provinces: see e.g. Kingsway General Insurance Co v Fekete Construction Co, 2011 ABQB 815, 60 Alta LR (5th) 408 at paras $12-13$.

Peninsular and Oriental Steam Navigation Co v Eastern Shipping Co, [1924] 1 WWR 97 at 99 (PC). Canadian courts regularly cite this decision: see e.g. Addison \& Leyen Ltd et al $v$ Fraser Milner Casgrain LLP et al, 2013 ABQB 473, 568 AR 130 at para 35; Srinivas v Panchapakesan, [1996] OJ No 1829 (QL) at para 37 (CT J (Gen Div)); Proctor v Seagram, [1925] 2 DLR 1112 at 1113 (ONCA). 
bring a motion to strike out the third-party claim as not disclosing a reasonable cause of action. This has been the undoing of many third-party claims in Canada. ${ }^{41}$

The case of Atkinson v. A.A. Murphy \& Sons Limited is illustrative. ${ }^{42}$ In that case, a radio commentator had read a letter on the air which the plaintiff alleged was libellous. The two defendants, the radio commentator and the station's owner, had brought third-party claims for contribution and indemnity against the owner of a newspaper which had previously published the letter but had not been sued. Hughes L.M. stated that "there must be a recognized basis of action, most commonly founded either in contract or tort, as between the defendant and the third party in order for the defendant to pursue third-party proceedings against the party he seeks to join in the action." ${ }^{43} \mathrm{He}$ concluded that, despite the similarity in the subject matter between the main action and the proposed third-party action, the complete absence of any legal relationship between the defendants and the proposed third party was fatal. ${ }^{44}$

Contrary to the Allan rule, Petersen Pontiac implicitly purports to ground a third-party claim for contribution and indemnity in the principles of contract law — absent any contractual relationship between the defendant and the proposed third party. Justice Hunt insists that there is no impediment in contract law to apportioning liability between independent contract breakers - without identifying the legal basis for the third-party claim in the first place. This unidentified issue infects the entire decision, and thus Petersen Pontiac cannot be accepted wholesale.

\section{The Equity Alternative}

In a single paragraph at the end of her decision, Justice Hunt stated without analysis that she could achieve the same result - namely, the apportionment of liability between Petersen Pontiac and Campbell — on the basis of equitable principles. ${ }^{45}$ Interestingly, the authorities that she cited in support of her main conclusion actually provide more support for a right of contribution among independent contract breakers founded in equity. For example, both Chief Justice Laskin in Giffels and Weinrib in his 1976 article entitled "Contribution in a Contractual Context" conclude that it would be inequitable for one independent contractor to bear more than his or her share of the plaintiff's loss or damage. ${ }^{46}$ Can equity supply the missing legal basis needed to bring third-party claims among independent contract breakers?

The law of restitution is separate from the law of contract. It is designed to prevent one person from being unjustly enriched at another's expense. For example, where a party makes part or full payment in money as the price under an oral contract, it is said to be inequitable to allow the promissor to keep both the land and the money. ${ }^{47}$ In 1943 , Lord Wright

$41 \quad$ See Misericordia Hospital v Acres Consulting Services Ltd (1977), 5 AR 254, (SC (TD)). See also Silliman Construction (Alberta) Ltd v Johnson, Ming \& Co (1981), 36 AR 407, (QB), rev'd on other grounds (1984), 53 AR 369 (CA).

(1973), [1974] 2 WWR 367 (Sask QB).

Ibid at 372 .

Ibid at 373.

Petersen Pontiac, supra note 2 at para 54.

Giffels, supra note 19 at 1355; Weinrib, supra note 17 at 340.

See Deglman v Guaranty Trust Co of Canada, [1954] SCR 725 at 728. 
eloquently articulated the purpose of restitution in the seminal House of Lords case of Fibrosa Spolka Akcyjna v. Fairbairn Lawson Combe Barbour, Ltd.:

It is clear that any civilized system of law is bound to provide remedies for cases of what has been called unjust enrichment or unjust benefit, that is to prevent a man from retaining the money of or some benefit derived from another which it is against conscience that he should keep. Such remedies in English law are generically different from remedies in contract or in tort, and are now recognized to fall within a third category of the common law which has been called quasi-contract or restitution. ${ }^{48}$

The right of contribution is rooted in both the common law and equity. ${ }^{49}$ In essence, it safeguards relative fairness among debtors who are subject to a common liability where one debtor must pay more than his or her share by permitting that debtor to bring a claim for contribution in respect of the excess amount against the co-debtors who were not sued..$^{50}$ Weinrib offers the following lucid description of the equitable right of contribution: "Inasmuch as D1 in discharging his own liability to $\mathrm{P}$ has relieved D2 of any need on his part to satisfy his own obligation to P, D1 has under the compulsion of law been forced to confer a benefit on D2 to which D2 is not entitled and which the device of contribution would force him to disgorge." 51

Equitable contribution applies among debtors who are liable in solidum, that is, subject to a common liability for the same debt. But independent contract breakers who caused or contributed to the same loss or damage have separate primary obligations and, thus, separate sources of liability. For this reason, independent contract breakers - the archetypal case being a builder and an architect both liable to an owner under separate contracts - have traditionally been thought to fall outside the scope of this equitable doctrine. ${ }^{52}$

The wisdom of this traditional view is dubious. The basic justification for a defendant's contribution claim is that another wrongdoer would be unjustly enriched if permitted to retain the benefit of having its share of a common liability or its total primary liability discharged by the claimant's payment. ${ }^{53}$ It is therefore far from inevitable that the notion of a common liability should preclude contribution among independent contract breakers. For example, in the builder-architect situation, the builder's act of satisfying a prospective judgment will necessarily confer a benefit on the architect — namely, the architect's obligation is diminished or extinguished — regardless of their initial sources of liability. ${ }^{54}$ Weinrib offers a persuasive exposition of the traditional view's flaw:

(1942), [1943] AC 32 (HL (Eng)) at 61.

Peter D Maddaugh \& John D McCamus, The Law of Restitution (Toronto: Canada Law Book, 2014) (loose-leaf updated 2014, release 14) vol 1, ch 9 at 1.

Lafrentz v M \& L Leasing Ltd Partnership, 2000 ABQB 714, [2001] 11 WWR 629 at para 30.

Weinrib, supra note 17 at 340 .

Maddaugh \& McCamus, supra note 49, ch 9 at 21; Weinrib, ibid; UK, "Working Paper No 59: Contribution" (1975) The Law Commission Working Paper No 59 at 10. For an example of the builderarchitect situation, see Dabous v Zuliani (1974), 6 OR (2d) 344, (H Ct J), rev'd in part (1976), 12 OR (2d) 230 (CA).

Maddaugh \& McCamus, ibid, ch 9 at 2.

As Weinrib observes, "[T]here is nothing mysterious in the notion of common liability. Those words do not embody a requirement that the liability of D1 and D2 share a single legal status, but simply that D1 and D2 be liable to the same person in such a way that the obligation of D2 is diminished or extinguished by the payment that D1 has been compelled to make": Weinrib, supra note 17 at 342 . 
Once it has been determined that the breaches of contract have caused the same loss and that the loss is translatable into money damages to which both parties are liable, the difference in initial obligation recedes into insignificance and the problem which remains is that of adjusting as between D1 and D2 the money damages which P can demand that either of them wholly pay. As far as P's ability to extract a remedy is concerned, both defendants are subject to a common demand, and there is thus no more reason as a matter of technicality than there is as a matter of fairness for denying the possibility of contribution. ${ }^{55}$

Since the traditional view has represented an intractable obstacle in achieving justice among independent contract breakers, Petersen Pontiac offers Canadian courts a valuable opportunity to revisit this position.

Today, unjust enrichment is incontrovertibly an independent cause of action. It provides a sound legal basis for bringing third-party claims in contract cases where the absence of a contractual relationship between the defendant and third-party would render a contract-lawbased contribution claim conceptually incoherent. It should apply equally in contract cases and mixed-contract-and-tort cases. ${ }^{56}$ This would properly recognize that contribution is a "unitary notion embodying a fundamental concept of restitutionary fairness that transcends the categories of contract and tort and for which those categories are irrelevant." ${ }^{, 57}$ It would also extend the principle underlying the right of contribution consistently throughout the civil law. ${ }^{58}$

\section{Concluding Thoughts}

Petersen Pontiac has now been cited in Alberta for its novel right of contribution on a handful of occasions. In Canadian Natural Resources Ltd. v. Arcelormittal Tubular Products Roman S.A., the Alberta Court of Appeal reiterated its approval of a right of contribution grounded in the basic principles of contract law:

[W]ith respect to whether or not there could be a claim for contribution at common law as between parties where each had its own separate contract with the plaintiff, this has now been answered in the affirmative by this court's recent decision in Isfeld v. Peterson Pontiac Buick GMC (Alta.) Inc. Therefore this ground of appeal must be dismissed. ${ }^{59}$

The Supreme Court of Canada refused leave to appeal from this decision. ${ }^{60}$ The problematic reasoning in Petersen Pontiac could thus be argued to have been sanctioned by the highest level of court in the country.

55 Ibid at 340 [emphasis in original].

Ibid at 345 .

Ibid at $344-45$.

Weinrib argues that the Negligence Act, supra note 26 and equivalent legislation in other provinces and territories can be "looked upon as a statement of public policy emanating from an authoritative source and can thus serve as a basis from which judges can reason by analogy": ibid at 344 . In this sense, recognizing contribution among independent contract breakers is simply one instance of a more general principle requiring the restitution of unjustly-realized gains at another's expense (ibid at 342). 2013 ABCA 279, [2013] 11 WWR 655 at para 37 [emphasis in original], leave to appeal to SCC refused, 35568 (6 February 2014). Ibid. 
In contrast, the Alberta Provincial Court in 1041400 Alberta Ltd. v. Amantea implicitly questioned Justice Hunt's contract law-based right of contribution. The Court cited Petersen Pontiac as authority for permitting a third-party claim for contribution in circumstances in which the statutory right of contribution did not apply, but it expressly grounded this right in equity rather than in contract law. ${ }^{61}$ Similarly, in Swift v. Eleven Eleven Architecture Inc., the Alberta Court of Appeal cited Petersen Pontiac but relied only on restitutionary principles to justify contribution among contract breakers. ${ }^{6}$ It had every opportunity to pick up on the contract law-based right of contribution. It elected not to do so.

To date, then, judicial treatment of Petersen Pontiac has been mixed. It is still too soon to draw conclusions about how courts, especially outside of Alberta, will react to Justice Hunt's decision. Will judges pick up on a contract law-based right of contribution? Or do decisions such as Amantea and Swift signal a trend towards judges preferring a right of contribution based on unjust enrichment principles instead?

To a great extent, Petersen Pontiac's legacy will depend on whether courts identify and correct the flaw at its heart by, as in Amantea and Swift, permitting third-party contribution claims in non-tort cases solely on the basis of equitable principles. If this change is made, Petersen Pontiac will provide Canadian courts with a long-awaited opportunity to extend the principle of relative fairness underlying the statutory right of contribution consistently throughout the civil law. It could therefore be highly persuasive outside of Alberta, obviating the need for legislative intervention. However, the equivocation at Petersen Pontiac's core could greatly reduce its persuasiveness in other jurisdictions and frustrate the progress that permitting contribution claims in non-tort cases would represent.

Worse yet, if the decision is accepted wholesale, it will yield an unwieldy and ill-defined concept of contribution, creating serious problems in practice. For example, how will courts contend with limitation of liability clauses? Under restitutionary principles, the answer flows logically from the nature of unjust enrichment. If a builder with a limitation clause and an architect without one were never both liable to a plaintiff for the same loss or damage, payment by the architect would not confer a benefit on the builder and, thus, there would be no basis for a contribution claim. ${ }^{63}$ It is unclear how courts could engage with this issue in a principled way relying on Petersen Pontiac's contract law-based right of contribution. Clarifying the legal basis for third-party claims for contribution and indemnity will therefore be a crucial adjunct to establishing a logically coherent right of contribution in non-tort cases.

In any event, Petersen Pontiac could prompt a dramatic increase in third-party claims in cases involving multiple people in contractual relationships with the plaintiff. Defendants will be incentivized to identify any other potential contract breaker who could reduce their exposure. In this way, Petersen Pontiac could generate many more large, multi-party, tortstyle lawsuits in contract or mixed-contract-and-tort cases, expanding the ambit of risk attending a breach of contract. Contract breakers would face the spectre of lawsuits by their

1041400 Alberta Ltd v Amantea, 2013 ABPC 214, 2013 ABPC 214 (CanLII) at para 22 [Amantea]. 2014 ABCA 49, [2014] 3 WWR 489 at para 63 [Swift].

Weinrib, supra note 17 at 346 . Weinrib provides a thorough treatment of these and other challenges to applying a right of contribution in a contractual setting, and he demonstrates how courts can resolve these challenges through equitable principles (ibid at 345-50). 
counterparties and by anyone their counterparties have sued who might have caused or contributed to the same loss or damage. This increased risk would be particularly acute in the construction industry, since construction projects often entail a web of contractual relationships, and in the legal services industry, since lawyers represent an obvious target for defendants seeking to "third party" any other potential contract breakers to reduce their exposure.

For these reasons, Petersen Pontiac is both a potential agent of confusion and an opportunity to meaningfully advance the law of contribution and indemnity. The authors strongly recommend that appeal courts take up the idea of a right of contribution based on restitutionary principles only, allowing the notion of a contract law-based right to fall by the wayside.

In light of Petersen Pontiac, reform through the common law is the most efficient method for achieving justice and fairness in this still-vexed area of law. But if courts fail to identify and correct the problems inherent to a contract law-based right of contribution, the difficulties that Petersen Pontiac might remedy will only become more intractable as parties are dragged through to trial, incurring thousands of dollars in legal fees. In the meantime, the very existence of a right of contribution among contract breakers, no less the proper legal basis for such a right, remains less than clear.

As a matter of fairness to defendants, appeal courts in Canada must resolve two problems: the absence of a recognized right of contribution among contract breakers and the incoherence at the heart of Petersen Pontiac. Failing such clarifying appeal-level authority, legislative intervention will become the only remaining means of correcting the problems currently infecting the law of contribution and indemnity in Canada. 
This page is blank - do not strip it in 